\title{
TRL SCALE LIMITS FOR POLICY FOR RESEARCH AND INNOVATION IN THE MILITARY FIELD
}

\author{
Toma PLEŞANU, Sorin PÎNZARIU \\ "Nicolae Bălcescu" Land Forces Academy, Sibiu, Romania \\ tomaplesanu@yahoo.co.uk, sorinpinz@yahoo.com
}

\begin{abstract}
At present, the TRL scale is used as an instrument in decision making regarding investments in research and development also at EU level. This requires different methods to make this instrument operational by adjusting (or understanding) TRL definitions. The scale must be adapted to the specific purpose of the funding by the EU of CDI programmes, because it does not approach the feedback mechanisms that are part of the innovation processes. This paper analyses conceptually and contextually the TRL scale also used in acquisitions of military equipment, in order to emphasize the necessity of the scale so that it corresponds to the purpose of the European decision makers.
\end{abstract}

Keywords: acquisition, technology readiness levels, key enabling technologies, manufacturing readiness levels, knowledge transfer partnerships

\section{The military acquisitions management system}

\subsection{Generalities}

The acquisition for defence system is a unique one, within which combat equipment, materials, facility development and services are planned, developed, purchased, maintained and used by the Ministry of National Defence. According to this system acquisitions include research, development, testing and evaluation, production, endowment of operational units and maintenance of the combat equipment.

Within the decision making process in the field of acquisitions there are three systems that participate, integrate and ensure the effectiveness of decisions: the requirement emission system; the acquisitions management system; the planning, programming and financing system.

The requirement emissions system, regulated by Instruction 1000.1 of the
Ministry of National Defence, is the responsibility of the General Staff and of the staffs of the services and is run by the Council for Requirement Oversight.

The acquisitions management system is the responsibility of the Armaments Department, being run by the Council for Defence Acquisitions - CODA and is regulated through Instruction 1000.2-01 of the Ministry of National Defence (MoND), establishing: the structuring of the acquisition process on the following phases; the analysis of several variants before beginning a programme of acquisitions, the taking into consideration of the most recent technological achievements, as well as of the information specific to acquisition programmes; the acquisition programme must have in mind the equitable sharing of risks between the MoND and the manufacturer; the attribution of the programmes for execution is done on the 
basis of competition; the costs, execution chart, performance parameters will be established at the beginning of the programme, and then will be evaluated and adjusted all along the programme; the decision at major points will be taken at the appropriate level, but at the lowest one possible.

The planning, programming and financing system is in the direct subordination of the minister of defence and has the responsibility to ensure the necessary conditions and funds for the execution of the acquisition programme, as well as the stability, together with the other two systems, of the resource allocation priorities as stated in the law of the budget.

\subsection{The process of acquisition management}

The process of acquisition management is structured on categories of acquisitions, on phases and points of decision (figure 1) that cover the entire duration of a programme, from its planning before it officially begins and the execution of all its phases of research, development, production, installation, logistic support, exploitation and tracking of the behaviour during use.

The costs are associated to each phase of the programme for its entire duration.

\begin{tabular}{|c|c|c|c|c|c|c|c|c|c|c|}
\hline \multicolumn{11}{|c|}{ Acquisition phases and decision points } \\
\hline \multicolumn{2}{|c|}{ Number of years $\rightarrow$} & \multirow{2}{*}{\multicolumn{2}{|c|}{$\begin{array}{l}0 \text { - } \\
\text { hase } 0 \text { - } \\
\text { ept selection } \\
\text { id study }\end{array}$}} & \multirow{2}{*}{\multicolumn{2}{|c|}{$\begin{array}{l}2- \\
\text { ase } 1- \\
\text { m (project) } \\
\text { finition }\end{array}$}} & \multirow{2}{*}{\multicolumn{2}{|c|}{$\begin{array}{l}\text { 4- } \\
\text { Phase } 2 \text { - } \\
\text { chnological } \\
\text { velopment }\end{array}$}} & \multicolumn{2}{|l|}{ 2- } & \multirow{2}{*}{\begin{tabular}{|c|}
$8-$ \\
Phase 4 - \\
Operation and \\
support
\end{tabular}} \\
\hline Phases & $\begin{array}{l}\text { Phase } 0 \\
\text { Preliminary } \\
\text { activities }\end{array}$ & & & & & & & $\begin{array}{r}\text { Phase } \\
\text { Produc } \\
\text { and inve } \\
\text { entr. }\end{array}$ & $\begin{array}{l}- \\
\text { on } \\
\text { tory }\end{array}$ & \\
\hline $\begin{array}{l}\text { Phase } \\
\text { target }\end{array}$ & $\begin{array}{l}\text { - Validated } \\
\text { threat evaluation } \\
\text { - Mission } \\
\text { Requirement } \\
\text { Document } \\
\text { preparation } \\
\text { - Alternative } \\
\text { methods } \\
\text { analysis }\end{array}$ & \multicolumn{2}{|c|}{$\begin{array}{l}\text { - Alternative } \\
\text { concepts } \\
\text { exploration } \\
\text { - System concept } \\
\text { definition } \\
\text { - Risk } \\
\text { assessment } \\
\text { - Acquisition } \\
\text { strategy and } \\
\text { objectives issue }\end{array}$} & \multicolumn{2}{|c|}{$\begin{array}{l}\text { - Project } \\
\text { characteristics and } \\
\text { capabilities } \\
\text { Definition } \\
\text { - Support } \\
\text { information for } \\
\text { phase } 2 \text { decision } \\
\text { preparation } \\
\text { - Acquisition } \\
\text { Program Base } \\
\text { establishment }\end{array}$} & \multicolumn{2}{|c|}{$\begin{array}{l}\text { - Most } \\
\text { favourable } \\
\text { phase } 1 \\
\text { program } \\
\text { translation } \\
\text { - Production } \\
\text { process } \\
\text { technology } \\
\text { validation } \\
\text { - System } \\
\text { capability test }\end{array}$} & \multicolumn{2}{|c|}{$\begin{array}{l}\text { - Production } \\
\text { and support } \\
\text { base } \\
\text { establishment } \\
\text { - Operational } \\
\text { capacity reach } \\
\text { - System } \\
\text { performance } \\
\text { monitoring }\end{array}$} & $\begin{array}{l}\text { - Troop } \\
\text { support } \\
\text { - Weak points } \\
\text { identification } \\
\text { - Upgrades } \\
\text { and required } \\
\text { upgrades } \\
\text { - Out of } \\
\text { inventory }\end{array}$ \\
\hline \multirow{3}{*}{$\begin{array}{l}\text { Decisi- } \\
\text { on } \\
\text { Points } \\
\text { DP }\end{array}$} & \multicolumn{2}{|l|}{ DP 0} & \multicolumn{2}{|c|}{ DP1 } & \multicolumn{2}{|c|}{ DP 2} & \multicolumn{2}{|c|}{ DP 3} & \multicolumn{2}{|r|}{ DP 4} \\
\hline & \multicolumn{2}{|c|}{ Concept study approval } & \multicolumn{2}{|c|}{$\begin{array}{c}\text { Program start } \\
\text { approval }\end{array}$} & \multicolumn{2}{|c|}{$\begin{array}{l}\text { Development } \\
\text { approval }\end{array}$} & \multicolumn{2}{|c|}{$\begin{array}{l}\text { Production } \\
\text { approval }\end{array}$} & \multicolumn{2}{|c|}{$\begin{array}{c}\text { Modification } \\
\text { approval }\end{array}$} \\
\hline & \multicolumn{2}{|c|}{ MDA, (CODA), DNM } & \multicolumn{2}{|c|}{$\begin{array}{c}\text { MDA, (CODA), } \\
\text { DCO }\end{array}$} & \multicolumn{2}{|c|}{$\mathrm{MDA},(\mathrm{CODA})$} & \multicolumn{2}{|c|}{$\begin{array}{c}\mathrm{MDA},(\mathrm{CODA}), \\
\text { RPI }\end{array}$} & \multicolumn{2}{|c|}{$\begin{array}{c}\mathrm{MDA},(\mathrm{CODA}) \\
\mathrm{RPI}\end{array}$} \\
\hline \multicolumn{11}{|c|}{ Abbreviation List } \\
\hline $\begin{array}{l}\bullet \\
\bullet\end{array}$ & \multicolumn{4}{|c|}{$\begin{array}{l}\text { MDA - Acquisition Memorandum } \\
\text { CODA - Council for Defence Acquisition } \\
\text { DNM - Mission Requirements Document }\end{array}$} & & \multicolumn{5}{|c|}{$\begin{array}{ll}\text { - } & \text { DCO - Operational Requirements Document } \\
\text { - } & \text { RPI - Abstract of Integrated Program } \\
\text { - } & \text { PD - Decision Point }\end{array}$} \\
\hline
\end{tabular}

Figure 1: Acquisition phases and decision points

Source: Adaptation after http://www.dpa.ro/engleza/simapa/achizitii/consilii/logic/faze.html

Achieving an armaments system usually takes $12-15$ years, from the identification of a deficiency / necessity in combat to the entry into use of a system that satisfies that deficiency / necessity.

The phases and decision points are as follows (figure 1):
- DP_0 (decision point 0$)$ - approval of the study of the concept, it authorises entry into phase "0", "Concept selection and study". In Phase " 0 " the possible variants to achieve the respective concept are studied; - DP_1 - approval of a new programme and entry into phase "1", "The defining of the system (project), approval of the acquisition 
strategy and the basis of the acquisition programme. The criteria for exit from phase 1 are established, according to financial constraints and limitations;

- DP_2 - approval of development and entry into phase "2", "Technological development";
- DP_3 - approval of production and entry into phase "3", "Production and installation";

- DP 4 - approval of modifications and entry into phase "4", "Operation and support".

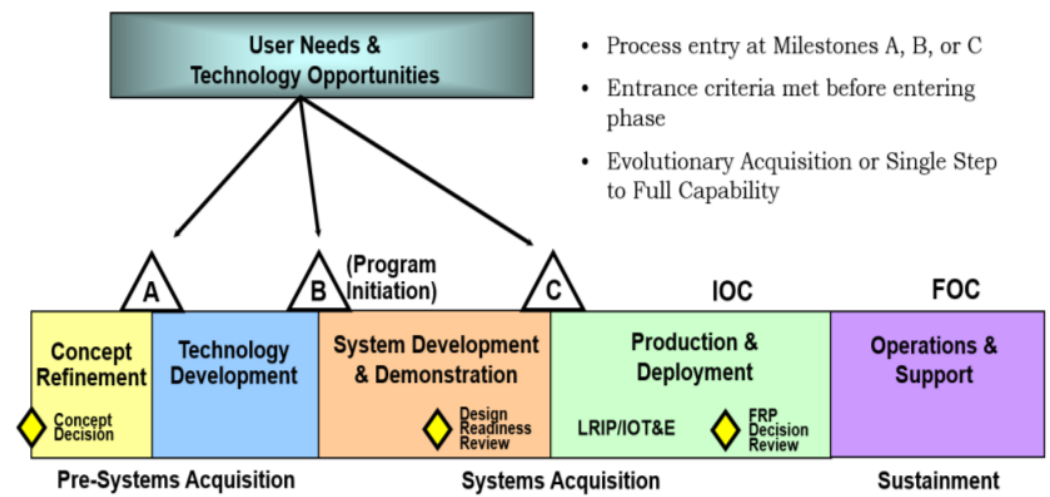

Figure 2: Representative Life Cycle for Defence Acquisition, per US DoD 5000.2,

Source: http://www.acq.osd.mil/dpap/Docs/new/5000.2\%2005-12-06.pdf, p.2

Since the elaboration of the instructions from the I-1000 series to the present (figure 1), the instruction from the DoD-5000 series have suffered a number of major transformations (figure 2 and 3). Thus, acquisitions were divided in three categories and the names of the phases were modified. In 2003, through what the Americans call the "reform in acquisitions", essential modifications were made to DoD5000 regulations (beginning with 12.05.2003), when the DoD-5000.1 and DoD-5000.2 directives/instructions were put into practice. Later on, in 2008 other modifications were made. A comparison between the old system (2003) and the one functioning since 2008, without considering an intermediary version, is displayed in figure 2 .

The new instructions place a major emphasis especially in technological, production, testing and evaluation issues, as well as on the total quantities to be produced. The latter problem is of great significance, especially in the current international context and in that of exacerbation of the competition in the production of military equipment. At Milestone B (figure 3), all the basic data of the acquisition have to be known, while at Milestone $\mathrm{C}$ the quantities to be purchased / sold externally have to be concretized.

\section{Limits of the TRL scale}

2.1 Technology Readiness Levels (TRLs) Achieving EU targets on competitiveness and growth requires covering all levels of the TRL scale, from basic research to viable commercial solutions available on the market (figure 4).

"The original TRL scale is based on the assumption that the innovation process is linear. Consequently, the TRL scale uses a linear approach of research, development and implementation, which is common with the dominant view on innovation at the beginning of the 1970s. The basic object of development is a single technology (component) that is developed and integrated in a more complex, highly technological product. Both aspects are a natural consequence of the fact that the TRL scale originates in the field of space systems development" [9]. 


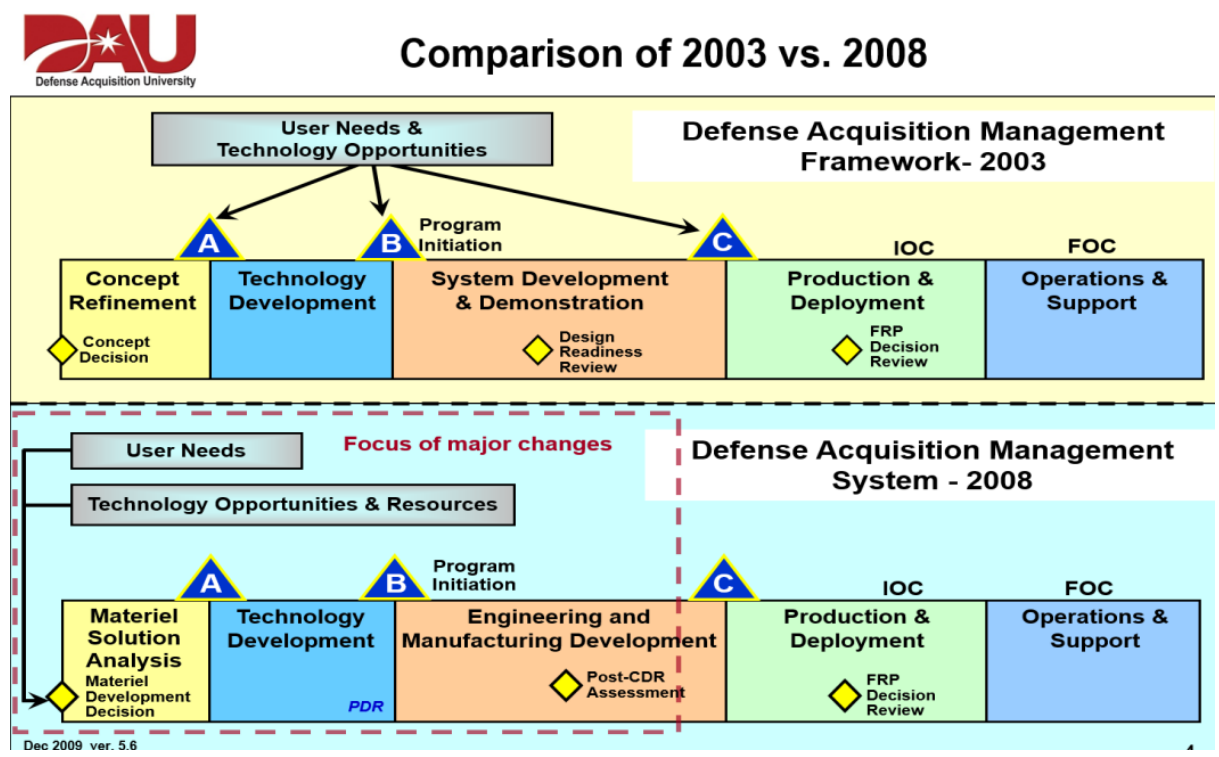

Figure 3: Machining The major differences between the 2003 and 2008 versions of the DoDI 5000.02 Source: http://images.slideplayer.com/24/7087701/slides/slide_4.jpg

The Innovation Chain: Converting Science into Wealth

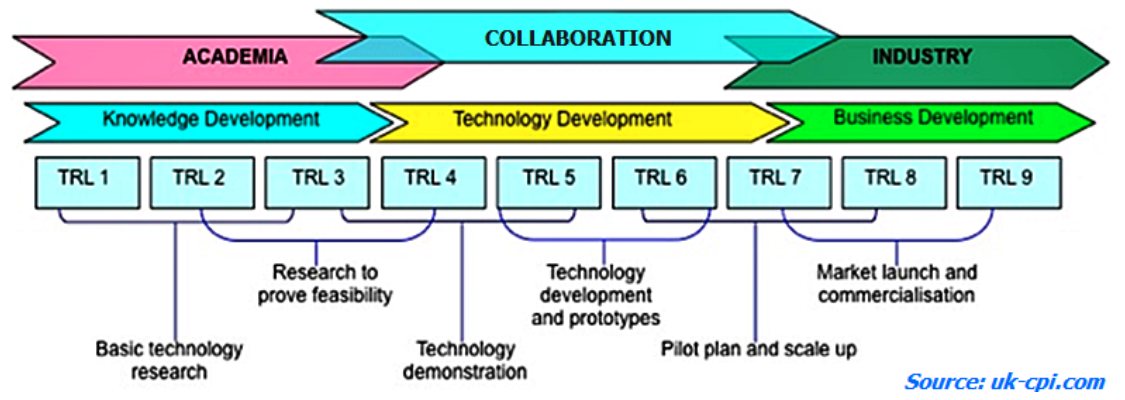

Figure 4: Technology Readiness Levels (TRLs)

Source: https://businesscolumnist.files.wordpress.com/2016/02/screen-shot-2013-05-03-at16_31_081.png

2.2 Key Enabling Technologies (KET) In the conception of the new research, development and innovation plan of the European Union "Horizon 2020", the industrial competitiveness can only be ensured on the basis of Key Enabling Technologies (KET). Their development and application must be done through a concentration and specialization of efforts at European level. Horizon 2020 lists the following KETs: nanotechnology, micro and nanoelectronics (including semiconductors); industrial biotechnologies; photonics; advanced materials; advanced production technologies.
The new plan starts from the idea that Europe has a very good scientific research, but its exploitation through industrial technologies and products with great market impact is achieved with difficulty, with delays and this profoundly affects the competitiveness of European companies. These generic technologies are in various maturing stages, and Europe's competitiveness in one field or another is different.

For this reason, emphasis is now placed on innovation, for the creation of new products and fabrication technologies. In this race to recover competitiveness, the Key Enabling 
Technologies (KETs) represent an essential vehicle.

The policy of KET development is explained through the bridge model in figure 5 which ensures the transformation of scientific knowledge into economic effect through products sold on the market. Once investments are done in this bridge, "crossing the valley becomes easier". This bridge over the "death valley" has three sections supported by three pillars. This formulation usually refers to the financially difficult journey (equivalent to the crossing of a canyon) that start-up companies have to make from the moment they begin to apply a proof of concept and until production and sales can ensure the financing of the firm. Indeed, there is a big probability that the company, despite the help received from risk capital and other financing schemes, succumbs to negative cash flows before these can be compensated for with its own income. It is to be noticed the fact that some firms survive being purchased by investors, the founders of the firm thus practically losing control over it. These are however happy cases, in which the concept is materialized into a product.

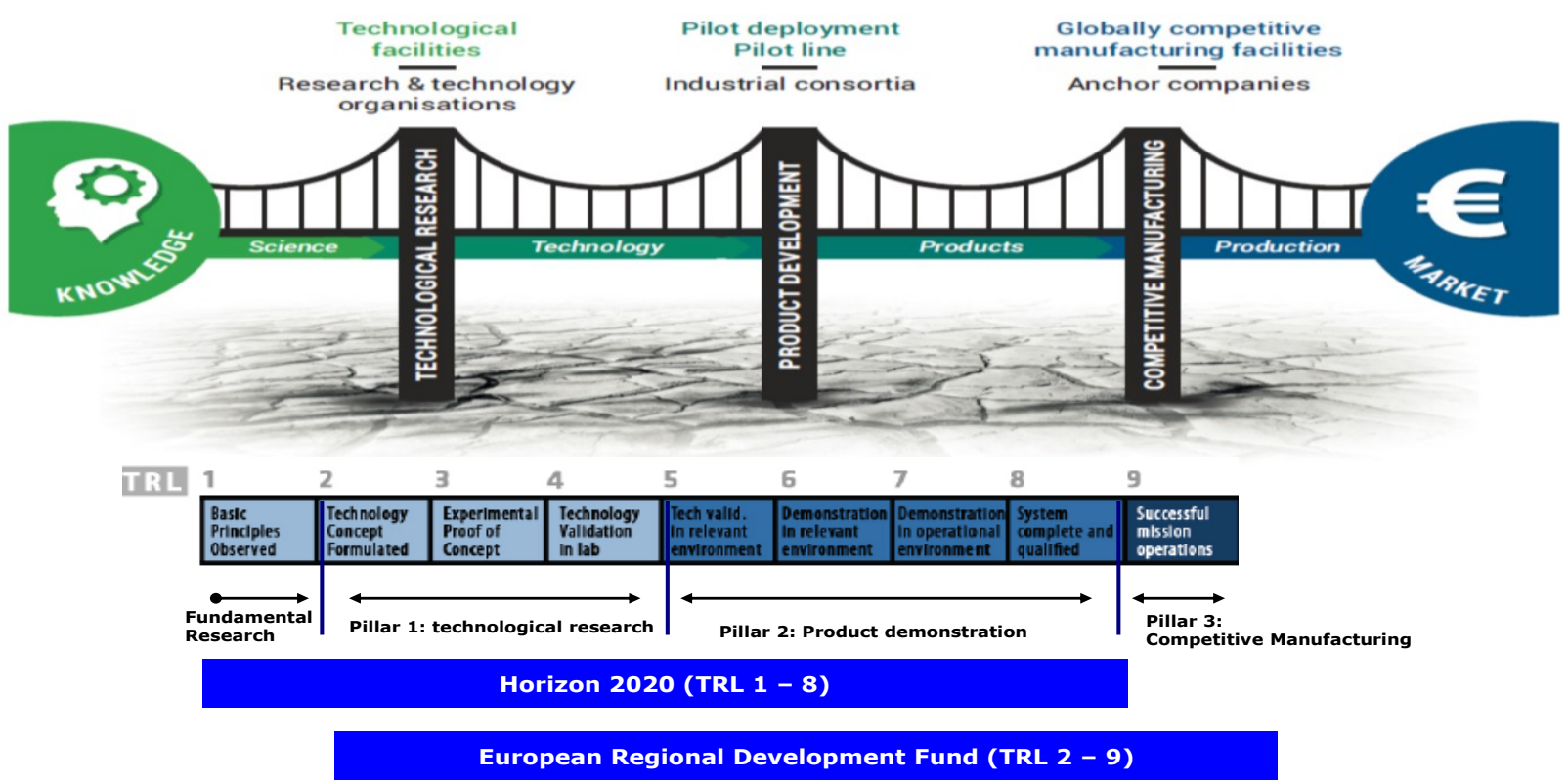

European Investment Bank (TRL 2 - 9)

Figure 5: Crossing the KETs "valley of death"

Source: Adaptation after [21], p.11

The first section of the bridge ensures the transformation of science into technology and is supported by the pillar named technological research. This has as its foundation the research-development organizations, and the research takes place in technological facilities. This is the stage of technological research and it is based on the experimental facilities that can be found in research-development organizations. It is important how these facilities are organized in order to ease innovation. Protection through internationally recognized patents is essential.
The second section of the bridge makes the transit from technology to product and is based on the product development pillar, which is founded on the industrial consortiums. It is the stage of the creation of the product demonstrator, which is done on a pilot line managed by the industrial consortium. This is where the step from technologies to product is done. Finally, the last section marks the passage from product to production and it is supported by the competitive fabrication pillar which is based on world level competitive production facilities, extant in 
key companies, capable of massive investments.

The bridge allows for the transit over a sequence of stages corresponding to the various levels of technological maturity. There is a multitude of factors influencing the transfer of knowledge into products, from governmental policies (financing programmes, fiscal policies, etc.) to the entrepreneurial and innovation culture. The existence of various companies interested in innovation and involved in the global competition as well as in a flexible academic environment represent favourable conditions. A general unitary policy for the stimulation of development and application of KET is envisaged, although the degree of maturity of these generic technologies is different, and the development conditions differ from one country to another.

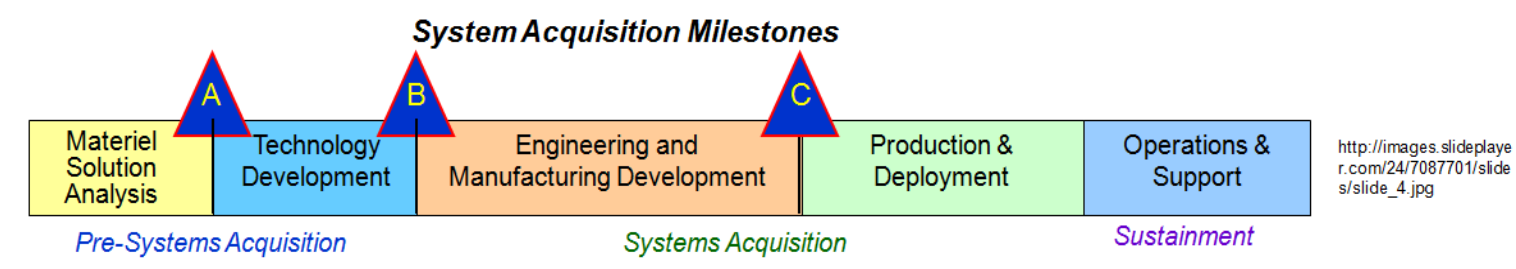

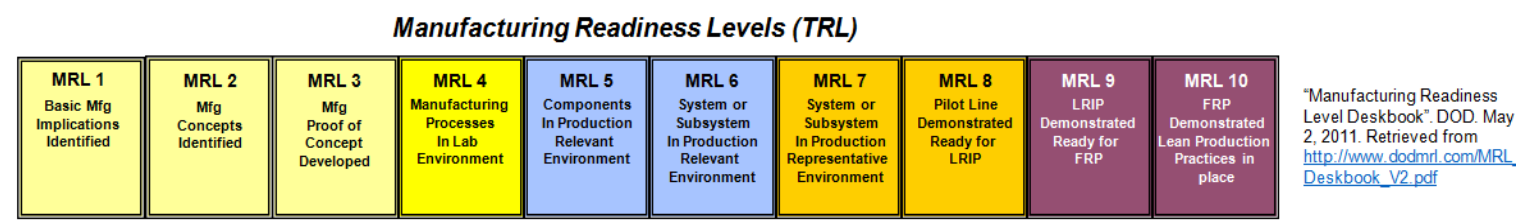

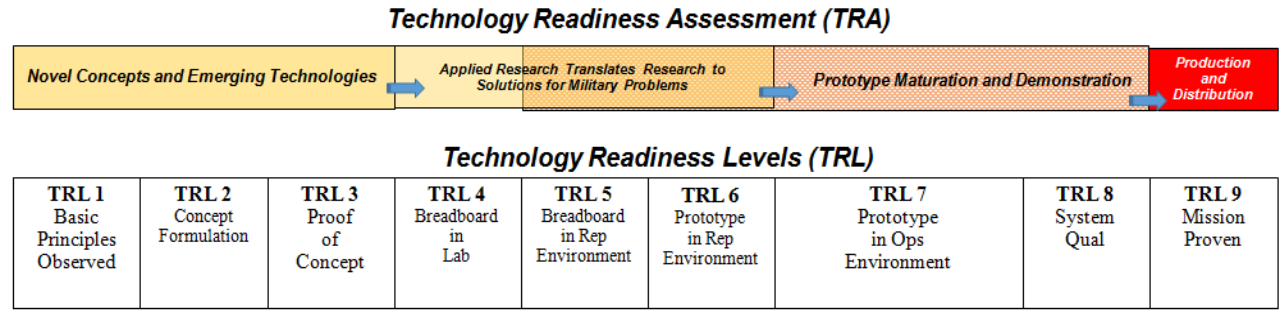

Figure 6: TRL-TRA-MRL Relationships
Technology Readiness Assessment RA) Deskbook, DOD, July 2009 \begin{tabular}{l}
$\begin{array}{l}\text { Retrieved from wnw. dtic mil/caj- } \\
\text { bin/GetTRD oc?AD=ADA524200, }\end{array}$ p.80 \\
\hline
\end{tabular} Technology Readiness Levels (TRL), DOD, Retrieved from http://www. aptcorpus.com/images/TRA_Deskbo ok_2011.pdf
The Key Enabling Technologies worked with the "Technology Readiness Levels (TRL)" scale (figure 5). This scale is being applied by many public and industry stakeholders (including the military) to assess the maturity of evolving technologies.

In order to ensure the successful transformation of research results into commercial products and services, it is also necessary to involve research and technology organizations (RTOs) in research activities. "RTOs are missionoriented providers of innovation services to governments and firms, dedicated to improving quality of life and building economic competitiveness" [12].
2.3 Knowledge Transfer Partnerships The key solution for crossing the bridge is represented by the partnership: A - a business partner in need of knowledge, B an academic partner with knowledge and $\mathrm{C}$ - the "associate" who transfers the knowledge. The main aim of this partnership is the transfer of knowledge, the configuration of basic research and its application to the needs of the business.

The knowledge transfer partnerships [6], if well managed, can lead to extraordinary research, using real data from the real world, and can help companies in the most pragmatic manners and can offer a valuable career experience to the key people involved. The partnership helps every partner obtain what they desire, be it the 
partner who models his/her career by obtaining the desired experience (C) (in some cases, the associates can work on their $\mathrm{PhD}$ thesis during the partnership. There is a specific budget for the professional development of the associate), be it the researcher by receiving their prioritized and written papers (B), as well as helping the company benefit from the transfer commercial knowledge (A).

\subsection{Manufacturing Readiness Levels (MRLs)}

The preparation for production uses the functions of production, quality assurance and essential industrial functions in order to obtain an operational capacity that will satisfy the mission needs - in the necessary quantity and quality for the accomplishment of the attributed missions at the "highs value".

The manufacturing readiness levels (MRLs) were elaborated within the DoD ManTech [15] programme by a government / industry working group in order to reflect the TRL structure and process [16]. The MRLs are composed of 10 levels, from the basic implications regarding production to the maximum rate production rate $(100 \%)$ and 9 criteria concentrated for each level, connected to the DoD acquisition process.

\section{Conclusions}

Although it has limitations, the TRL scale is largely used to assess individual technologies to reduce budget risks and planning. The TRL scale is often tailored to the specific needs of an organization. The levels of technological preparedness are often grouped in order to produce a concise scale / classification.

The MRLs offer a common language and standard for [17]: the evaluation of the production maturity of a technology, a product or production process; the understanding of the level of production risk to produce a system or technology of transition to a system; the integration of the production process in the acquisition process; the establishment of the agenda for the production risk management; the obtaining of production maturity at critical decision points in the acquisition; the identification of potential risk zones through independent production evaluations.

The Horizon 2020 working programme uses the TRL scale in order to make a decision with regard to the type of projects to be financed at the proposed TRL level, presented in the description of calls. Adaptation does not pay much attention to the challenges of production, although the TRL 9 includes the element of "competitive production". The TRL scale is used for different organizational needs, depending on the purpose. The TRL scale can be used for planning, comparative assessment and communication purposes and can be a support tool for making investment decisions. Usually, this is done by adapting the scale to the specific purpose of the organization.

\section{References}

[1] Kayuha, R. J.R.; Leclaire, C.; Matthews, R. H.; Henry, L. M.. Integrated Project Management Handbook. Dayton Aerospace, 4141 Colonel Glenn Highway, Suite 252, Dayton, Ohio, February 2002.

[2] Pleşanu, Toma; Mihai, Nicuşor, Military production in Romania during the communist era and its effect on the organizational culture, Bulletin of the 'Carol I' National Defence University, number 1, pp.14-18, 2015, buletinul.unap.ro/pagini/pdf/2015/01-2015en/buletin-2015-en.pdf.

[3] Pleşanu, Toma; Managementul sistemelor de achiziţii, Editura Universităţii Naţionale de Apărare „Carol I”, Bucureşti, 2005, ISBN 973-663-300-4. 
[4] ISO 16290:2013- Space systems - Definition of the Technology Readiness Levels (TRLs) and their criteria of assessment Guidelines for the use of TRLs in ESA programmes, 21 August 2013.

[5] https:// engineerimpact.wordpress.com/ 2014/ 02/ 15/ knowledge-transfer-partnershipsdisseminating-embedding-and-using-research-for-real/.

[6] https://www.cheatography.com/davidpol/cheat-sheets/dod-technology-readiness-levels/.

[7] http://acqnotes.com/acqnote/acquisitions/jcids-overview.

[8] http://www.acq.osd.mil/dpap/Docs/new/5000.2\%2005-12-06.pdf.

[9] https://www.nasa.gov/pdf/458490main_TRL_Definitions.pdf.

[10]http://www.aptcorp-us.com/images/TRA_Deskbook_2011.pdf.

[11] http://www.aptcorp-us.com/images/MRL_Deffinitions_2010.pdf.

[12] http://www.earto.eu/fileadmin/content/03_Publications/The_TRL_Scale_as_a_R_I_Polic y_Tool___EARTO_Recommendations_-_Final.pdf.

[13] http://www.imt.ro/NANOPROSPECT/raport_mai_2011/Raport_NANOPROSPECT_faza II.pdf.

[14]https:// www.dodmantech.com/ Institutes/ Files/ MfgUSA_A-Third-Party-Evaluation-ofProgram-Design-and-Progress_Jan2017.pdf.

[15]http://www.aptcorp-us.com/images/MRL_Overview_Chart_V7.pdf.

[16] http://www.aptcorp-us.com/trlintroduction.html.

[17] https:// www.directives.doe.gov/ directives-documents/ 400-series/ 0413.3-EGuide-04a/ @@images/ file.

[18] http://images.slideplayer.com/24/7087701/slides/slide_4.jpg .

[19] https://serkanbolat.com/2016/02/17/technology-readiness-level-trl-put-into-practice/.

[20] http://aries.ucsd.edu/ARIES/MEETINGS/0712/Waganer/TRL\%20Calc\%20Ver\%202_2.xls.

[21] http://ec.europa.eu/transparency/regexpert/index.cfm?do=groupDetail.groupDetailDoc\&i $\mathrm{d}=22113 \&$ no $=2$. 